\title{
FEDERAL AID FOR STATE LAW ENFORCEMENT
}

\author{
PAUL H. SANDERs*
}

It has become a truism that the problems connected with crime have very little regard for state boundaries. A realization of this fact has led the federal government to take an increasingly greater interest in criminal phenomena which have heretofore been left to the states or to the void where no government has claimed jurisdiction. But it would scarcely be asserted that the scope of the "commerce clause" and other bases of federal jurisdiction could be extended under our present constitutional system so as to allow the federal law to deal directly with all crime and the problems associated therewith. This fact, in the minds of many, does not eliminate an urgent need for a concerted, nation-wide attack, federally directed or controlled, on the "crime problem" in fields other than those we have come to regard as federal. At least one writer, believing that the matter is the concern of the nation as a whole, has asserted that there should be a federalization of our major criminal law and its administration. ${ }^{1}$ But grant the necessity of a united approach on crime in the extrafederal field and the necessity of raising standards of law-enforcement personnel in the states; it still does not follow that it is necessary to undergo the cumbersome process of constitutional amendment to reach that result. Such a proposal overlooks the fact that there is available a device which has been used in the United States and elsewhere to enable the central government to control affairs that were theoretically beyond its jurisdiction. The device makes use of "federal aid" or "grants-in-aid" and acquires its names accordingly. Some indication of what is meant by "federal aid," its use in various fields, and its possible application in the improvement of state law enforcement will be discussed here.

In a day when many calls are made on the federal government of this country, it may seem that the use of the term "federal aid" to indicate a particularized device of government is not very fortunate. As used in this article it will designate, in brief, a scheme in which the central government agrees to pay part of the cost of an undertaking within the jurisdiction of a local government if the latter will pay the remainder of the cost, and if the central or federal government is allowed, to a varying

* A.B., r931, Austin College; LL.B., 1934, Duke University School of Law. Holder of a fellowship in the Columbia University School of Law, 1934-35.

${ }^{2}$ Schumacher, Federalization of Our Major Criminal Law and its Administration (1934) 4 Docket 3671 . 
extent, to say how the total amount so appropriated by the two governments is to be expended.

Some applications of this principle to the betterment of state law enforcement come to mind at once. It might be provided that the federal government would pay part of the cost of law enforcement in each state that would agree to coördinate the law enforcing agencies within the state under a state department of justice. It was the recommendation of the American Bar Association at the recent meeting in Milwaukee that such a department be created in each state. Federal aid might very well be the incentive that would make that recommendation bear fruit. Again, the agreement of the federal government to help pay for local law enforcement might be conditioned on the meeting of certain educational and other standards by the law enforcement personnel within the state. This would very likely lead to revolutionary changes in the internal politics of the various states, but if the problem of efficient law enforcement personnel were solved thereby it is doubtful if many would regard the cost as too great. If this device could to any considerable extent coördinate the law enforcing agencies of the states and consequently of the nation, and if it could at the same time raise the standards of the personnel of those agencies, it is worth the serious consideration of those interested in meeting the challenge of crime. Before going more fully into the use of federal aid in the improvement of state law enforcement an examination will be made of its use in other countries and in other fields here in the United States.

\section{EMployment of "Grants-in-Aid" Abroad}

The system of a central government subsidizing smaller governmental units for the purpose of raising the level of efficiency in various fields had its origin in England under the distinctive title of "grants-in-aid."2 These were for the avowed purpose of overcoming local poverty, making possible a fairly high minimum standard of efficiency over the whole country and providing a sanction for the exercise of a regulatory and inspectatorial power by the central authority. The system started under Sir Robert Peel in 1846 with helps in agriculture. This led in turn to grants for education, police, public health, roads, poor relief, and housing. While some of these fields were obviously not central, nevertheless they were considered the concern of the state as a whole, because the social causes, as well as the benefits of the expenditures, were wider than any local area. Yet complete centralization, which would be unadaptable to local circumstances, was avoided.

In France ${ }^{3}$ central aid (subventions) is given to the departments on conditions of efficiency and the sanctioning of local schemes by the central body. The communes in turn are subsidized by both central and departmental governments under definite conditions for such services as roads, health, care of children, fire brigades, water supply, education, agricultural experimental stations, motor and tramway service, and elec-

${ }^{2}$ Sec Grants-in-Aid (1932) 7 Excrc. Soc. Scr. 152, et seq.

${ }^{3}$ Id. at 153 . 
trification. In Switzerland ${ }^{4}$ even more than in England there was a strong feeling of local sovereignty to be overcome, but subventionen are given under detailed specifications and supervision by the federal government. The results have been important and beneficial. In spite of the fact that in these countries there is no necessity of pondering the complexities of "sovereignty" as it is said to exist in the United States, it is significant that the principle under consideration has actually been used in the aid of local law enforcement, and that the same factors which called for its use abroad exist in the United States today, aggravated by our peculiar problems.

\section{Growth of Federal Aid in United States}

There have been an increasing number of federal aid projects in the United States since the beginning of the present century, ${ }^{5}$ but the inception of the idea was first expressed in a bill introduced in Congress in $1857^{6}$ that provided for the donating of certain public lands to the states to be used for the endowment of agricultural and mechanical colleges. This bill passed both houses of Congress, although arousing the ire of ardent supporters of states' rights, but it was vetoed by President Buchanan. In I862 the bill became law, ${ }^{7}$ providing a few limitations on the investment of the funds and reports as to the progress of the colleges. In I8go the so-called "Second Morrill Act"8 was passed which provided for the further endowment of the landgrant colleges and for the further extension of federal supervision. The contribution of this Act to the evolution of federal aid is important in that it gave the Secretary of the Interior the power to withhold its annual allotment from any institution not fulfilling its obligations. This was the first time that the federal government had found a weapon in its hands with which to force state compliance with its requirements. Real federal supervision of state activities became a possibility. Legislation in $1887^{9}$ and $1906^{10}$ with regard to agricultural experiment stations in connection with the colleges already established completed the pattern followed by subsequent federal aid legislation in this country. The general scheme involved in federal aid is, as indicated above, that in return for a federal appropriation the states will in turn appropriate money for a certain purpose, and the way in which the whole amount is to be spent, including the qualifications of the personnel employed, may, to a varying extent, be controlled by the federal government. In addition to the agricultural and mechanical colleges, and the agricultural experiment stations already mentioned, federal aid has been given under the scheme outlined for forest fire prevention, ${ }^{11}$ agricultural extension work, ${ }^{12}$ building and maintaining high-

\footnotetext{
II. at 154 .

'Sec, in gencral, Warren, Congress as Santa Claus (1932) 92 et seq; Burdick, Federal Aid Legislation, 8 CoRn. L. Q. 324 .

${ }^{6}$ H. R. No. 2, CoNic. Glone, 35th Cong., Ist Sess., r739 (1858).

I2 Stat. 503 (1862). ${ }_{24}$ STat. 440 (1887).

${ }_{26} 6$ Stat. 417 (1890). ${ }^{10} 34$ Stat. 63 (I906).

12 Weeks Act, $3^{6}$ Stat. 961 (19ז1); Clarke-MeNary Act, 43 STAT. 653 (1924).

${ }^{12}$ Smith-Lever Act, 38 STAT. 372 (1914).
} 
ways, ${ }^{13}$ equipping and training the state militia, better known as the National Guard, ${ }^{14}$ vocational education, ${ }^{15}$ vocational rehabilitation, ${ }^{16}$ and for the hygiene of maternity and infancy. ${ }^{17}$

One objection that may have occurred to the reader is that very little could be accomplished by a plan for federal aid in the improvement of state law enforcement unless the states accept the plan first-and there is nothing to force them to accept it. However, the states are practically unanimous in their support of these federal aid programs. Only seven states failed to accept the rehabilitation law and three the infant and maternity hygiene act; one state has no National Guard, and while several have not accepted the provisions of the forest fire prevention act it has been because these states have no forest fire problem. Except as noted, every state has accepted every subsidy. Whether this acceptance has been influenced by a desire to coöperate or whether any state has been unwilling to see other states getting their portion of the federal funds without seeking a share itself is another question which may be better answered after an examination of some of the plans in practice.

Examination in detail of some of these federal aid programs should, moreover, reveal situations analogous to those that would arise if a plan of federal aid for state law enforcement were in operation, and at the same time indicate the sort of administrative set-up that should be used for such a plan. Federal aid for highways is one application of our general principle that will be described with great particularity both because it illustrates a wide application of that principle in the amount of federal aid involved and the rigid federal supervision that accompanies it, and because its subject matter is sufficiently simple to afford a clear picture of the direct application of the device without any obscuring complexities.

\section{Federal Aid For Highways}

The Federal Aid Road Act ${ }^{18}$ directs the Secretary of Agriculture to expend money, in coöperation with the highway departments of the several states, in the construction of rural "post roads."19 Construction, reconstruction, and improvement of the highways is to be financed in part with federal funds, but the upkeep of the roads is to be the responsibility of the states. Although at first the Secretary of Agriculture could insure federal maintenance requirements only by refusing to approve any further project in a delinquent state until its federal aid roads had been put in proper condition, yet subsequently the federal government was given the

${ }^{23}$ Federal Aid Road Act, 39 Stat. 355 (1916).

"Dick Act, 32 Stat. 775 (1903); National Defense Act, 39 Stat. 197 (1916).

${ }^{20}$ Smith-Hughes Act, 39 STAT. 929 (x917).

${ }^{13}$ Fess-Kenyon Act, $4 \mathrm{I}$ STAT. 735 (1920).

${ }^{17}$ Sheppard-Towner Act, 42 STAT. 224 (1921), repealed, 44 STAT. 1024 (1927).

${ }^{25}$ Supra note 13.

${ }^{20}$ The "post roads" wording was probably used to circumvent attacks on the constitutionality of the act. However, these words have not in practice been restrictive since a "post road" was declared to be any public road over which the United States mails "now are or may hereafter be transported." (Italics added.) After I92I the phrase "post road" was dropped altogether. See 42 STat. 212 (192I). 
power to keep such roads in proper condition and to charge the state for the same, such charge to be repaid before any further aid would be given. ${ }^{20}$ It is necessary that this plan be formally accepted by the state legislature, although a temporary acceptance by the governor is allowed. Each coöperating state submits to the Secretary of Agriculture, through its highway department, proposed projects, with plans, specifications, and estimates. The Act defines in some detail the manner in which the federal funds may be spent, and it is necessary that proposed projects meet the federal requirements before they can be approved. Work on the projects is supervised by the state department but is subject to the inspection and approval of federal officials. $^{21}$

The administration of the Act is given to the Bureau of Public Roads; the actual work of supervision is in the hands of a chief engineer with headquarters in Washington. For administrative purposes the country is divided into eleven districts, each with a district engineer, who deals with the state highway departments and makes many final decisions. Under the district engineer are the state engineers. These latter have as many assistants as are necessary, and are directly responsible for affairs within their jurisdiction. Important matters and questions of policy are referred to Washington or, in the West, to San Francisco, where a deputy chief engineer is stationed. The federal officials deal only with the state officials, not with the contractors engaged in actual construction work. However, a federal representative is generally present when bids are submitted, and his approval of the bid is a prerequisite to a grant of federal aid.

Note that the administrative set-up in a plan to aid state law enforcement would not need as large a field force as is used in this program. However, the use of a division into districts would be useful in checking on the states' use of federal funds, as well as in enabling the federal government to keep in closer touch with local problems.

The types of roads have not been severely limited by the Bureau, and the kinds of construction have been as diverse as the needs of the various sections of the country, although certain standard engineering practices have been required. (This would indicate the possibility of a like flexibility in meeting the peculiar law enforcement problems of the various states.) Under this Act, by 1926 , there had been more than 7,000 federal aid projects, involving 56,000 miles of highways.

It has been observed that in this subsidy, as in no other, there has been complete and intensive examination of the recipient of federal funds. Federal representatives visit regularly every project in which federal money has been invested. This Act has been instrumental in centralizing highway control within the state, since it was provided that the federal government was to deal with the state highway department. When the Act was passed sixteen states had no such departments, and in others it was not really in control of road building. To a large extent this has been changed.

${ }^{\infty} I d$.

${ }_{39}$ STAT. 355 (rgr6). 
This experience affords an encouraging precedent for the plan of state departments of justice already referred to.

The Bureau of Public Roads has been free from partisan politics. Its chief (in I930) was selected because he was conceded to be one of the two best highway engineers in the country. ${ }^{22}$ While there can be no active interference in the affairs of the state departments, a strong negative influence can be exercised. Furthermore, requests have been made that incompetent state employees be transferred to other than federal projects. States have found the federal aid a method of escaping the complaints of the local politician who may desire that a highway be routed past his farm or who may seek similar favors. The state official can truthfully say that the federal government will approve only the best route, regardless of the effect that this has on local politicians. If conditions within a state become too flagrant, then federal funds may be withdrawn from it altogether. This happened in the case of one state, and it was found that the withdrawal was a most potent weapon. Here again is an indication that federal aid could be a powerful element in eliminating political interference with the program and personnel of state law enforcement agencies.

Figures for 1934 show every state to be coöperating with the federal government, and only one-Montana in $1925^{23}$ - has ever refused to match the federal funds.

Professor A. F. Macdonald, author of a thorough-going study of federal aid and its operation, canvassed the highway engineers of forty-one states to ascertain their conception of the effect of the Act. ${ }^{24}$ Thirty-one emphatically stated that federal aid had stimulated road building within their jurisdictions. One was uncertain as to the matter, and nine said that construction would have proceeded just about as fast in their states if there had been no federal offer. Twenty-seven state highway engineers were of the opinion that they were building better roads because of federal coöperation. Only two of the forty-one engineers said that federal officials interfered unreasonably with their plans and policies. This fact coupled with the intense supervision that has been carried on in connection with this work by the federal government is a most significant testimonial to the tact with which the federal administrative agency has acted.

It is interesting to note that since the inception of the federal program the states have learned a great deal about working together in planning their arterial highways, exchanging information concerning improved practices, and numerous other matters. Indirectly federal aid has led to the adoption of uniform road markers and to the organization of the American Association of State Highway Officials. From this it is reasonable to believe that a federal aid plan for state law enforcement would lead to greater coöperation among the states in this field. Coördination of

\footnotetext{
${ }^{2}$ Macdonald, Federal Aid (r928) ro4. The writer has drawn extensively on Professor Macdonald's work in the preparation of this paper.

${ }^{2}$ Montana quickly repented, however, and voted to coöperate with the federal government by the largest majority that has ever been given in the state to an initiative measure. Id, at Io8.

${ }^{24}$ Id. at II I et seq.
} 
the law enforcing agencies of adjoining states under federal supervision could-and should-become an integral part of any plan for federal aid. A genuine incentive could be substituted for the vague hopes and recommendations of coöperation between states now current.

\section{Federal Aid for Vocational Training}

The federal aid for highways resulted from an act that described in detail how everything was to be carried out. In the plan for vocational education now to be examined the very opposite is true-a very general act has been translated into definite requirements by the administrative agency. Yet both programs have worked remarkably well. The work done by the supervising agency in the vocational education program suggests that it would be the best type for use in the improvement of state law enforcement.

The Smith-Hughes $\mathrm{Act}^{25}$ provides for a comprehensive system of vocational training in the common, wage-earning employments. It provides three schemes by which the states can coöperate with the federal government. First an appropriation is provided for federal aid to the states in paying salaries of teachers, supervisors, or directors of agricultural subjects, this to be apportioned among the participating states on the basis of rural population. A similar appropriation is provided for teachers of trades, home economics, and industrial subjects, the apportionment to be based on urban population. An appropriation is also made for preparing teachers for these subjects, and this is to be distributed with the total population as a basis. It is necessary for this offer to be accepted by the state legislatures, with the appointment of the state treasurers as custodian of the federal funds.

As is usual in such legislation, the state is to match the federal funds, but the federal funds can be used only for the training and salaries of teachers. Expenditures for buildings, equipment and other requisites are to be made entirely by states or local communities. In this way the federal government can supervise the expenditure of a sum far in excess of double the amount of federal funds that are contributed.

The federal grant is also conditioned on the appointment or creation by the state of a board consisting of at least three persons, vested with the power to coopperate with the Federal Board for Vocational Education in the administration of the Act. Imposed on the state boards is the duty of preparing, in considerable detail, plans showing the manner in which the joint federal and state funds are to be used. These plans are to show the kinds of vocational education that would be developed, the schools and equipment that would be used, the qualifications of the teachers employed, etc., and are to be submitted to the Federal Board for approval. Federal funds may be withheld if the Federal Board determines that a state is not meeting the requirements of the approved plans. The need of a similar group in each state for a law-enforcement improvement plan is apparent. This set-up indicates a means

${ }_{39}{ }_{39}$ STAT. 929 ( 1917 ). 
whereby a federal aid plan could effect improvement in the standards of state lawenforcement officers.

The Board for Vocational Education has four ex-officio members and three are appointed. It has translated the rather general requirements of the Act into a great many specific requirements. The Act itself, for instance, provides that the state board shall establish requirements for teachers of agricultural subjects with the approval of the Federal Board $;{ }^{26}$ the Federal Board has assisted the state with certain "suggestions" as to the requirements. It has not been dictatorial in such matters. Tact has been used. Yet the states know that they will lose their allotments unless the federal recommendations are adopted. The Federal Board has, moreover, felt free to insist on good buildings and equipment although this must come wholly out of state funds. Recognition of local conditions has kept the Federal Board from requiring the same standards of every state, and allowance has even been made for differing conditions within the state. Supervision of such work within a state is necessarily less thorough than in the case of highways. Still a fairly close check is established, especially in those states that have shown ignorance of the purpose of the Act or unwillingness to coöperate.

In checking the results of this act, Macdonald's survey ${ }^{27}$ shows that every state director questioned emphatically denied federal domination. Thirty-three of the thirty-five declared that federal funds had stimulated vocational education within their states. Some even went so far as to say that there would have been no program of vocational education in their state at all but for the stimulus of federal aid.

An interesting fact in this connection shows that federal aid will act as a stimulant where free federal advice will not. No provision for commercial education is contained in the Act, yet the Federal Board has a division devoted to this, ready to help the states solve their problems when called. But as a consequence of the lack of federal aid, no state board for vocational or general education has developed programs of commercial education comparable to the programs that they have developed in the other fields of vocational education. ${ }^{28}$ This is in line with the statements of twenty-six of the thirty-five state directors that state standards had been raised by contact with the Federal Board, some feeling that federal aid tended to raise the standards of general education as well. The special studies and investigations made by the Federal Board are thus being disseminated on the widest scale.

\section{Appraisal of Federai Aid in United States}

The scope of this paper does not permit an examination of all the fields of federal aid. Macdonald's surveys in the fields other than those already discussed lead him to conclude that: ${ }^{29}$

I. Federal aid has stimulated state interest and state activity.

2. It has raised state standards and established a national minimum of efficiency.

$\approx$ Id. at 935 .

${ }^{2 \pi}$ Macdonald, op. cit. supra note 22, 173 et seq.

${ }^{25}$ Id. at 177 .

${ }^{9}$ Id. at 269 et seq. 
3. It has produced a certain degree of standardization.

4. It has made possible, however, the continued recognition of local needs.

5. It has not resulted in federal domination. There has been no unreasonable federal interference with state policies or with the details of state administration.

6. It has equalized to some extent the tax burdens of the several states. The equalizing process has been somewhat haphazard, but has proved reasonably satisfactory.

7. It has not succeeded in eliminating state politics.

8. It has tended however to reduce the amount of state politics, and has increased greatly the efficiency of state workers originally selected for political reasons.

9. The federal bureaus administering the subsidy laws are free from politics.

10. The thoroughness of federal supervision varies greatly from bureau to bureau. Some bureaus supervise very carefully; others make little more than nominal inspections. More thorough supervision by some bureaus would greatly increase their effectiveness. . . .

\section{Constitutionality of Aid for a Non-Federal Purpose}

Before turning to a more specific consideration of a plan of federal aid for state law enforcement, notice should be taken of the single constitutional problem presented by such a plan. May Congress spend money for something that lies outside the field which it may directly affect by its legislation? Article I, Section 8 , of the Constitution of the United States states, "The Congress shall have Power To lay and collect Taxes, Duties, Imposts and Excises, to pay the Debts and provide for the common Defense and general Welfare of the United States; ..." The meaning of the "general welfare clause" has excited comment almost from the beginning of our Constitutional history, ${ }^{30}$ and the debate is still going on. ${ }^{31}$ Some feel with Madison that under the clause Congress can only appropriate funds for purposes within the scope of its enumerated powers; others agree with Hamilton that the "spending power" is not so limited. The question is more or less academic however since Congress actually has used the broadest possible interpretation of the clause as a basis for the appropriation of billions of dollars ever since the Civil War, ${ }^{32}$ and its broad construction of the clause has never been successfully questioned.

\footnotetext{
- James Madison believed that the federal government's field of taxation and expenditure did not extend beyond its other powers. He is quoted by Warren, op. cit. supra note 5, at p. 7 , "Whenever, therefore, money has been raised by the General Authority, and is to be applied to a particular measure, a question arises whether the particular measure be within the enumerated authorities vested in Congress. If it be, the money requisite for it may be applied to it; if it be not, no such application can be made." Alexander Hamilton, on the other hand, believed that there was no such restriction. In his Report on

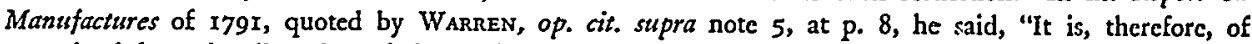
necessity left to the discretion of the National Legislature to pronounce upon the objects which concern the General Welfare, and for which, under that description, an appropriation of moncy is requisite and proper. And there seems to be no room for a doube that whatever concerns the general interests of learning, of agriculture, of manufacture, and of commerce, are within the sphere of the National Coun* cils, as far as regards the application of money."

${ }^{31}$ See, in general, Warren, op. cit. supra note 5, and Corwin, The Spending Power of Congress (1923) 36 HaRv. L. REv. 548 .

${ }^{3}$ The legal significance of this practice was admirably stated in a brief of the present Chicf Justice Charles E. Hughes in Smith v. Kansas City T. \& T. Co., 255 U. S. 180, 4 I Sup. Ct. 243 (I92I): "There can be no question as to the continuous practical construction of the powers of Congress to raise and appropriate money to the effect that this power is not limited to the objects enumerated in the subsequent provisions, but extends what may properly be deemed to be embraced within the general welfare as
} 
The Sheppard-Towner Maternity Act ${ }^{33}$ is the only federal aid legislation, of the sort with which we are concerned, that has been questioned in the courts. In addition to the general question of the power of Congress to spend money for such a purpose, there were many who felt that such legislation was unconstitutional because it violated the sovereignty of the states, since under it the federal government invaded realms that were formerly supposed to be wholly within the power of the state. Certain of the states that contributed largely to the federal treasury objected likewise because their contributions were going to help states that contributed very little. ${ }^{34}$

Frothingham, a citizen of Massachusetts, sought in a taxpayer's suit to restrain the Secretary of the Treasury from making payments to the states under the provisions of the Maternity Act because the statute unreasonably increased her tax burden, thereby depriving her of property without due process of law. When this case was carried to the Supreme Court of the United States it was joined with another original suit brought by the Commonwealth of Massachusetts for itself and as representative of its citizens against the Secretary of the Treasury. The State's main contention was that the effect of the law was to impose upon each state the "illegal and unconstitutional option either to yield to the Federal Government a part of its reserved rights or lose the share which it would otherwise be entitled to receive of the moneys appropriated."

The Supreme Court dismissed the cases for lack of jurisdiction. ${ }^{33}$ As to the State's suit, it was said that since the Act did not require that the plaintiff do or yield anything, and since the Act imposed no burden other than that of taxation, which falls not on the State but on its inhabitants, who are within the federal as well as the state taxing power, the complaint amounted to a contention that Congress had usurped the powers of the states by the mere enactment of a statute, although nothing could be done under that statute without the state's consent. The question thus presented the Court held to be a political and not a judicial one, and therefore not subject to be determined by the exercise of judicial power. ${ }^{36}$ A State may not, as parens patriae, institute judicial proceedings to protect her citizens (who

expressly provided in the clause which confers the taxing power itself. As Mr. Chief Justice Marshall said in McCulloch v. Maryland, 4 Wheat. 316, 40r: 'An exposition of the Constitution, deliberately established by legislative acts, on the faith of which an immense property has been advanced, ought not to be lightly disregarded." (Reprinted in Corwin, supra note 31 , at 579, n. 84, and in 72 Cong. Rec. 7890 (1930)). Justice Story, whose influence in development of Constitutional theory has been large, agreed with this interpretation of the clause. I STORY, Constitution (5th ed. I89r) \$99r.

3 In United States v. Realty Co., 163 U. S. 427 , 16 Sup. Ct. II20 (1896), the question of bounties was considered, but the constitutional question was evaded.

at should be noted here that Macdonald completely refutes the argument that the state which pays a large amount into the federal treasury in income taxes and other forms of revenue is being cheated when it receives less aid in proportion to what it pays in than the poorer state, by showing that in many of the richer states income taxes are paid on corporate and other incomes although very little of those incomes is derived within the state. Furthermore federal services in general are not given on the basis of what is paid into the federal government but on the basis of need, which is, of course, the only sensible plan. Macdonald, op. cit. supra note 5, 246-252, 264-266.

${ }^{5}$ Massachusetts v. Mellon, Frothingham v. Mellon, 262 U. S. 447, 43 Sup. Ct. 597 (1923).

${ }^{30}$ Id. at 482,43 Sup. Ct. at 599. 
are no less citizens of the United States), from the operation of a federal staute on the grounds that, as applied to them, it is unconstitutional. ${ }^{37}$

As to the individual's suit the Court indicated that his injury, if any, was too minute and added, "We have no power per se to review and annul acts of Congress on the grounds of unconstitutionality. That question may be considered only when [there is] a direct injury suffered or threatened. ... The party who invokes the power must be able to show not only that the statute is invalid but that he has sustained ... some direct injury as a result of its enforcement, and not merely that he suffers in some indefinite way in common with people generally."38 Otherwise the Court will not step in and prevent a coequal department of the government from acting under an allegedly unconstitutional statute.

These decisions would seem to dispose of the possibility of a federal aid statute being questioned in the courts, a result which, it must be conceded, has been regarded by some writers as unfortunate..$^{39}$

\section{Conclusion}

Analogies drawn in considering the use of federal aid in other fields indicate that there is a very fair prospect of its proving of great value in the betterment of state law enforcement. But difficulties peculiar to the problem of law enforcement cannot be ignored. Before Congress would be in a position to appropriate federal funds for the aid of state law enforcement agencies, an extended period of study, of consultation and conference with the state and local officials, would seem essential. And since the Department of Justice is not at present equipped to undertake this task, the creation of a special advisory board charged with the duty of formulating a scheme for federal aid would seem a wise preliminary to action.

The problems faced by such a board would be three-fold. It would have to plan the machinery for the administration of the act, not only within the federal government but for the states as well. It would have to devise an equitable method of distributing funds among states whose needs and resources vary greatly. Finally, it would have to determine whether the conditions upon which the funds thus allocated would be paid should be specified in the statute or should be left to the discretion of the body charged with the act's administration. In the former event, it would have to prescribe these conditions; in the latter, to furnish standards and principles to guide in their subsequent formulation.

It would be folly to couple a proposal for the creation of such a body with an attempt to anticipate its work. Yet a few general predictions may be hazarded. It would seem inevitable that the administration of such an act would be vested in the Department of Justice which already and to an increasing degree coöperates with state and local officials engaged in crime repression. It seems equally predictable

${ }^{3 \pi}$ Id. at 485,43 Sup. Ct. at 600 .

${ }^{3}$ Id. at 488,43 Sup. Ct. at 6or.

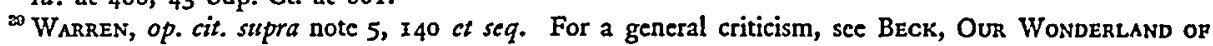
BUREAUCRACY (1932). 
that the creation of some central body in each state clothed with the power not only to deal with the federal administrative body but also to coördinate and supervise the activities of local units receiving federal aid would be found necessary. How this could be done without unduly sacrificing local autonomy would be one of the most difficult problems faced in devising a federal aid scheme.

Highly important if the full benefits of federal aid were to be enjoyed would be the creation of a planning and research unit within the federal organization which could serve as a clearing house for the dissemination of the results of research carried on by it and by other investigatory and research bodies. Through its aid and counsel, it could assist state and local agencies to achieve and maintain the standards set under the federal statute.

It seems clear, moreover, that these standards, whatever their other ramifications, would include requirements as to personnel which would ultimately lead to the emancipation of law enforcement agencies from political domination. With the growing efficiency in personnel, a corresponding increase in the efficiency of methods employed in crime repression would follow, and these benefits would not be confined to the wealthier, more progressive communities. Eventually a federal aid program might embrace the problems incident to the treatment of the prisoner. Probation, prison discipline, and parole, each offers a field where improved standards would readily flow from the stimulus of federal aid conditioned on their adoption.

This paper has sought to present the potentialities which the federal aid plan holds for improved law enforcement. Although the difficulties in its way have not been emphasized, there has been no intention to minimize them. If the goal is a worthy one, they should serve only as a challenge to intelligent, concerted action. 